ppi $201502 Z U 4645$

Esta publicación cientifica en formato digital es continuidad de la revista impresa ISSN-Versión Impresa 0798-1406 / ISSN-Versión on line 2542-3185Depósito legal pp

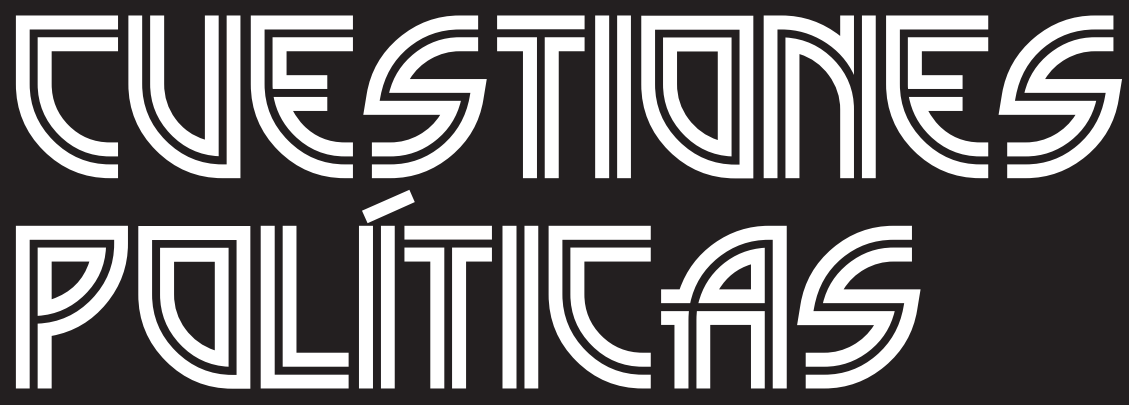

Instituto de Estudios Políticos y Derecho Público "Dr. Humberto J. La Roche' de la Facultad de Ciencias Jurídicas y Políticas de la Universidad del Zulia Maracaibo, Venezuela
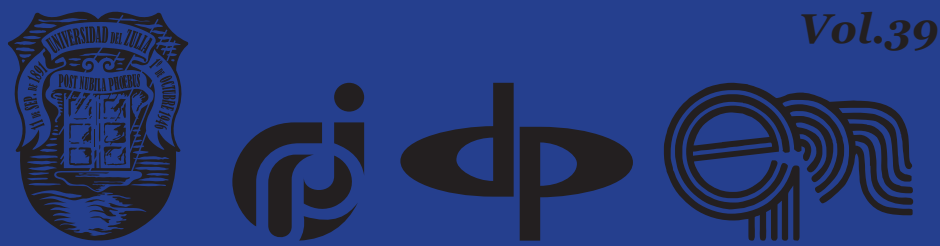


\title{
Legal basis for ethical behavior of civil servants in Ukraine: some problematic issues
}

\author{
DOI: https://doi.org/10.46398/cuestpol.3968.57
}

\author{
Zvarych Roman Vasylovych ${ }^{*}$ \\ Havretska Maryna Yosypivna ${ }^{2 *}$ \\ Andrukhiv Oleh Ihorovych ${ }^{* * *}$ \\ Kaleniuk Oksana Mykolayivna ${ }^{4 * * *}$ \\ Boiko Ihor Yosypovych ${ }^{* * * * *}$
}

\begin{abstract}
The objective of the article is to consider the legal basis for regulating the rules of ethical conduct of civil servants in Ukraine and, at the same time, to compare them with the relevant legislative framework of other countries. The subject of the study is the analysis of the legal basis for regulating the rules of ethical conduct of public officials in Ukraine. The research methodology includes the following methods: normative and dogmatic method, hermeneutic method, method of analysis and synthesis, dialectical method, legal and comparative method, legal modeling method. It is concluded that there is only one special legal act to regulate the ethics of public officials in Ukraine, but it is not binding, as it does not have the appropriate legal means of influence. Practical involvement. Based on international experience, it was concluded that Ukraine should adopt its own Code of Ethics for public
\end{abstract} officials.

Keywords: code of ethics; civil servant; misconduct; legal basis; international ethical experience.

* Doctor of Law, Professor, Dean of the Social and Applied Sciences Department King Danylo University Private Higher Educational Institution. ORCID ID: https://orcid.org/oooo-0002-3296-9591. Email: roman.zvarych@ukd.edu.ua

** Ph. D, Associate Professor of the Department of Law of King Danylo University Private Higher Educational Institution. ORCID ID: https://orcid.org/oooo-0oo1-6743-7854. Email: maryna. havretska@ukd.edu.ua

*** Doctor of Law, Professor of the Department of Law of King Danylo University Private Higher Educational Institution. ORCID ID: https://orcid.org/oooo-0003-4871-0143. Email: oleh.andrukhiv@ukd.edu.ua

**** Ph.D in Law, Assistant Professor, Vice-chancellor for Scientific and Educational Work of King Danylo University Private Higher Educational Institution. ORCID ID: https://orcid.org/oooo-0002-34438209. Email: oksana.kaleniuk@ukd.edu.ua

***** Head of the Department of State History, Law and Political and Legal Studies of Faculty of Law of Ivan Franko National University of Lviv, Doctor of Law, Professor. ORCID ID: https://orcid.org/ooooooo3-1377-2328. Email: boikoboiko@ukr.net 


\section{Base jurídica para el comportamiento ético de los funcionarios públicos en Ucrania: algunas cuestiones problemáticas}

\section{Resumen}

El objetivo del artículo es considerar la base legal para regular las reglas de conducta ética de los funcionarios públicos en Ucrania y, al mismo tiempo, compararlas con el marco legislativo pertinente de otros países. El tema del estudio es el análisis de la base legal para regular las reglas de conducta ética de los funcionarios públicos en Ucrania. La metodología de investigación incluye los siguientes métodos: método normativo y dogmático, método de hermenéutica, método de análisis y síntesis, método dialéctico, método legal y comparativo, método de modelado legal. Se concluye que sólo existe un acto jurídico especial para regular la ética de los funcionarios públicos en Ucrania, pero no es vinculante, ya que no cuenta con los medios legales de influencia adecuados. Implicación práctica. Sobre la base de la experiencia internacional, se llegó a la conclusión de que Ucrania debería adoptar su propio Código de Ética para los funcionarios públicos.

Palabras clave: código de ética; funcionario público; conducta impropia; fundamento jurídico; experiencia ética internacional.

\section{Introduction}

Civil service is a manifestation of special trust on the part of society and the State; it places high demands on the moral qualities of civil servants. In order to be effective, civil service should be based on a solid spiritual and moral foundation. The goals of civil service, its guiding principles, norms, professional requirements for its staff have a moral aspect, which decisively determines its focus and the main dominants. The moral atmosphere in the authorities, dishonesty of the responsible official can seriously discredit any good intentions of the government. The authority of civil servants is rightly associated primarily with their decency, justice in public opinion.

The ethics of public service is closely linked to the social structure of a particular society and is clearly defined by it. This, as a rule, reflects the traditional ideas of the community about the status of their society in general, the superiority of their civilization, etc. At the same time, the ethics of civil service is a combination of universal rules that are applied throughout the civilized world. All this necessitates the constant understanding, research and improvement of ethical norms of the civil service, which, in turn, will contribute to the achievement of strategic goals of the State. 
Zvarych Roman Vasylovych, Havretska Maryna Yosypivna, Andrukhiv Oleh Ihorovych, Kaleniuk Oksana Mykolayivna y Boiko Ihor Yosypovych

884

Legal basis for ethical behavior of civil servants in Ukraine: some problematic issues

In the light of the foregoing, the aim of the article is to consider the legal basis for regulating the rules of ethical conduct of civil servants in Ukraine, to compare them with the relevant legislative framework of other countries and to draw relevant conclusions and propositions.

\section{Methodology}

The methodology of the Article is based on general and special methods of scientific knowledge. For example, normative and dogmatic method as well as the method of hermeneutics were used in the process of studying domestic legal acts and the legal acts of foreign countries regulating the problem of ethical behavior of civil servants. The method of analysis and synthesis helped to clarify the content of legal mechanism governing the studied issue in Ukraine and in some other States. Dialectical method allowed to identify the problems of legal framework for ethical behavior of civil servants in Ukraine. Legal and comparative method was applied when comparing legal foundation for regulating ethical behavior of civil servants in Ukraine and in some other countries. Legal modeling method made it possible to formulate the relevant conclusions and propositions.

\section{Literature Review}

The analysis of foreign literature made it possible to identify modern approaches to the ethical education of civil servants in Western democracies. The works of a number of scientists (Dewey, Edlem, Savarin, Wright) are devoted to the problems of teaching ethics to civil servants. They developed two approaches in their researches. The first one is broad, represented by Dewey (2008). He argues that education builds up character, and therefore, every discipline teaches ethics through proper maintenance. Since public administration as a scientific field covers politics, law, management, ethics, economics, business, sociology, psychology, mathematics, etc., the content and methods of each discipline should be considered in the context of the subject of this phenomenon (Wright, 1994).

The second approach is to introduce a special course in professional ethics into the curriculum. Western scholars pay considerable attention to the problem of ethically conscious management of subordinates. This is due to the peculiarities of formal management relations in the system of "manager-subordinate", primarily their asymmetric structure. Besides, the manager, in addition to the institutional responsibility for the results of work, also has humanitarian responsibility (Kuhn and Weibler, 2004). The practice of government ethics and the responsibility of officials has been an important topic of research by foreign authors in recent years. This is due to the transition to a "new government" - managerialism, and 
the development of the European Union as a community of democracies. These studies are presented by scientific works of foreign authors on the ethics of civil servants, which were carried out within the Public Management Service of the Organization for Economic Cooperation and Development - OECD, materials of discussions at seminars on ethics in public administration (ENA), annual international conferences on ethics (Easton, 1962), publications of Transparency International.

Some of the issues of the ethical behavior of civil servants were considered by Kolomoiets et al. (2019), Kolomoiets et al. (2020), Malimon and Shevchenko (2015), Sorokina (2017) and others.

\section{Results and Discussion}

Article 19 of the Constitution of Ukraine (LU 254k/96-VR/1996, June 28) stipulates that "State authorities and local governments, their officials are obliged to act only on the basis, within the powers and in the manner prescribed by the Constitution and laws of Ukraine". The main of such laws is the Law "On the Public Service" (LU 889-VIII/2016, December 12), Art. 8 of which sets ethical requirements for civil servants. Thus, in accordance with the provisions of this article, he (she) is obliged to: 1) comply with the Constitution and laws of Ukraine, act only on the basis, within the powers and in the manner prescribed by the Constitution and laws of Ukraine; 2) adhere to the principles of civil service and rules of ethical conduct; 3) respect human dignity, prevent violations of human and civil rights and freedoms; 4) treat the State symbols of Ukraine with respect; 5) use the State language in the performance of their official duties, prevent discrimination against the State language and counteract possible attempts to discriminate against it; 6) ensure, within the limits of the powers granted, the effective performance of the tasks and functions of State bodies; 7) conscientiously and professionally perform their duties and the terms of the contract for civil service (in case of conclusion); 8) execute decisions of the State bodies, orders (instructions) of the heads on the basis and within the powers provided by the Constitution and laws of Ukraine; 9) comply with the requirements of the legislation in the area of prevention and counteraction to corruption; 10) prevent the emergence of a real, potential conflict of interest in the course of civil service; 11) constantly increase the level of their professional competence and improve the organization of official activities; 12) keep State secrets and personal data of persons who became known to him (her) in connection with the performance of his (her) official duties, as well as other information that is not subject to disclosure in accordance with the law; 13) provide public information within the limits set by law.

Besides, the above-mentioned Law contains other articles, the title of which, although does not explicitly state the requirements for the conduct 
Zvarych Roman Vasylovych, Havretska Maryna Yosypivna, Andrukhiv Oleh Ihorovych, Kaleniuk Oksana Mykolayivna y Boiko Ihor Yosypovych

of these subjects, but their content is directly related to this issue. Thus, Art. 10 enshrines the requirement for political impartiality of a civil servant. The latter should impartially carry out lawful orders (instructions), instructions of heads, regardless of their party affiliation and political beliefs. He (she) has no right to demonstrate his (her) political views and commit other acts or omissions that may in any way indicate his (her) special attitude towards political parties and negatively affect the image of the State body and trust in the government or threaten the constitutional order, territorial integrity and national security, for the health and rights and freedoms of the others.

Art. 36 prescribes the duty of a civil servant to take the Oath of a civil servant when appointing to a civil service position for the first time. If a person refuses to take the Oath of Civil Servant, he / she shall be deemed to have refused to hold a civil service position, and the act on his / her appointment to the position shall be revoked by the subject of appointment. The text of the Oath indicates the priority role of the Constitution. The civil service is based on constitutional provisions. They are the ethical constraints on the actions of a civil servant and the basis for public trust. In case of conflict between the Constitution and another normative act or order of the head, an employee who adheres to ethical principles will be faithful to the Constitution (Sorokina, 2017).

Section 8 "Disciplinary and material liability of civil servants" provides sanctions for persons who violated the requirements of regulations in the area of civil service, committed an act incompatible with the status of a civil servant, did not perform or improperly performed their duties, etc.; that is, this section is also directly related to the ethical conduct of civil servants. Another legal act that regulates relations in this area is the Law of Ukraine "On Service in Local Self-Government Bodies" (LU 2493-III/2001, June 07). Art. 8 of this Law establishes that the main responsibilities of local government officials are: 1) adherence to the Constitution and laws of Ukraine, other regulations, acts of local governments; ensuring, in accordance with their powers, the effective operation of local selfgovernment bodies; 2) observance of human and civil rights and freedoms; 3) preservation of State secrets, information about citizens that became known to them in connection with the performance of their official duties, as well as other information that is not subject to disclosure in accordance with the law; 4) constant improvement of the organization of the work, increase of professional qualification; 5) conscientious attitude to performance of official duties, initiative and creativity in work; 6) respectful attitude to citizens and their appeals to local governments, care for a high level of culture, communication and behavior, the authority of bodies and officials of local government; 7) prevention of actions or omission that may harm the interests of local self-government and the State. 
Another Law that directly sets out the requirements for the ethical conduct of civil servants is the Law of Ukraine "On Corruption Prevention" (LU 1700-VII/2014, October 14) (Section 6). According to the provisions of this section, civil servant is obliged to strictly observe the requirements of the law and generally accepted ethical norms of conduct, be polite in relations with citizens, managers, colleagues and subordinates; act exclusively in the interests of the State or territorial community when representing them; adhere to political neutrality; avoid demonstrations in any form of one's own political beliefs or views; not to use official powers in the interests of political parties or their branches or individual politicians; act impartially, regardless of private interests, personal attitude to any person, their political views, ideological, religious or other personal views or beliefs; honestly, competently, timely, effectively and responsibly perform official duties and professional duties, decisions and instructions of bodies and persons to whom they are subordinated, accountable or controlled; prevent abuse and inefficient use of State and communal property; not to disclose or otherwise use confidential and other information with limited access, which became known to him (her) in connection with the performance of his (her) official duties and professional duties; refrain from executing decisions or instructions of management if they are contrary to the law, regardless of private interests.

Requirements for ethical conduct of civil servants are also indirectly contained in a number of other laws of Ukraine. Thus, the Law of Ukraine "On the clearance of the authorities" (LU 1682-VII/2014, September 16) was adopted in order to prevent the participation in the management of public affairs of persons who by their decisions, actions or omission carried out measures (and / or facilitated their implementation) aimed at usurping power by the odious former President of Ukraine Viktor Yanukovych , undermining the foundations of national security and defense of Ukraine or unlawful violation of human rights and freedoms, i.e. in order to prohibit them from holding certain positions (in the service) in public authorities and local governments. Accordingly, this Law establishes certain ethical norms of conduct for persons performing the functions of State power and local self-government.

The Labor Code (LU 322-VIII/1971, December 10) establishes mandatory discipline requirements for all employees (including civil servants). Thus, employees are obliged to work honestly and conscientiously, timely and accurately follow the instructions of the owner or his (her) authorized body, comply with labor and technological discipline, the requirements of regulations on labor protection, treat the owner's property carefully (Article 139).

The issue of ethical conduct of civil servants is covered by some laws of Ukraine, but, unfortunately, it remains insufficiently regulated. This 
Zvarych Roman Vasylovych, Havretska Maryna Yosypivna, Andrukhiv Oleh Ihorovych, Kaleniuk Oksana Mykolayivna y Boiko Ihor Yosypovych

is due to the number of problems related to the formation of the level of ethics of civil servant: firstly, there is a great need for highly qualified personnel knowing theory and practice of regional development; are able to work in conditions of fierce professional competition and have a high stress-resistant threshold and adhere to ethical and moral norms in business relations. Secondly, it is the lack of appropriate professional (and sometimes specialized) education and the level of professional training, which is a mandatory requirement for holding public office. Thirdly, it is insufficient legislative and legal enshrinement and coverage of moral norms for civil servants, as well as insufficient responsibility for violating these norms (Sorokina, 2017).

That is why in 2012 a special Law "On the rules of Ethical Behavior" (LU 4722-VI/2012, May 17), which defined the guidelines for the conduct of persons authorized to perform the functions of the State or local selfgovernment and the procedure for prosecuting them for violating such norms, was adopted. In addition to such general principles of service as observance of the rule of law, priority of interests of the State or territorial community, political impartiality, tolerance, observance of the principle of objectivity, honesty, competence, timeliness, efficiency and responsibility in the performance of official duties, confidence in government, confidentiality execution of illegal decisions or orders, the Law prescribes such important rules as prevention of conflict of interests, prevention of illegal benefit or gift (donation) and declaration of property, income, expenses and obligations of a financial nature.

However, in 2014, this Law expired on the basis of the enactment of the Law of Ukraine "On Prevention of Corruption", which we have already considered above. No special law was adopted instead, but in 2016 the National Agency of Ukraine for Civil Service approved the Rules of ethical behavior for civil servants and officials of local government (General Rules) (Order of the National Agency of Ukraine for Civil Service Affairs 2016, August 05). These General Rules are generalization of the standards of ethical conduct for civil servants and local government officials, which they are obliged to follow in the performance of their duties.

The Order consists of five sections. Section "General Provisions", in particular, states that the main purpose of the work civil servants and local government officials is to serve the people of Ukraine and the territorial community, to protect and promote the rights, freedoms and legitimate interests of an individual and a citizen. The behavior of civil servants and local self-government officials should ensure public confidence in the civil service and service in local self-government bodies. Ethical behavior of civil servants and local government officials is based on the principles of civil service and service in local governments. 
Section 2 is entitled "General Responsibilities of Civil Servants and Local Government Officials". It stipulates that civil servants and officials of local self-government should act only on the basis, within the powers and in the manner prescribed by the Constitution and laws of Ukraine, as well as international treaties, recognized by the Verkhovna Rada of Ukraine when performing their official duties. Civil servants should honestly, competently, effectively and responsibly perform their duties, take the initiative, as well as evasion of decision-making and responsibility for their actions and decisions, timely and accurate execution of decisions of State bodies, local governments, orders, instructions of managers within the powers; in case of receiving the order (instruction), which civil servant considers illegal or such as threatening the rights, freedoms or interests protected by the law of separate citizens, legal entities, the State or public interests, he (she) has to inform about it the head of the body in which he (she) works in writing immediately.

Section 3 "Abuse of official position" stipulates that a civil servant and a local government official should use their official position exclusively to perform their official duties and instructions of managers, provided on the basis and within the powers provided by the laws of Ukraine. In short, a civil servant is prohibited from abuse his (her) official position to commit acts of corruption. It is also impossible not to mention the prohibition for civil servants and local government officials to abuse their official position for political purposes, as well as in personal (private) interests or in illegal personal interests of others, including the use of their status and information about the place of work in order to obtain illegal benefits for themselves or others.

Section 4 is entitled "Use of resources of the State and the territorial community". The resources of the State and the territorial community are understood as movable and immovable property, funds, official information, technologies, intellectual property, working hours, reputation, etc. It is the duty of civil servants to use State and communal property rationally and carefully, to constantly increase the efficiency of its use, avoiding excessive and unnecessary costs, and to prevent the abuse and use of State or communal property or funds in private interests. It is also emphasized that the working hours of a civil servant and local government official should be used to perform their official duties.

Section 5 "Use of Information" contains rules related to prohibitions and restrictions on the processing of personal data of individuals, confidential and other information with limited access in accordance with the law. Thus, if civil servants or local government officials become aware of the threat or facts of unauthorized dissemination of information with limited access, they must immediately notify the immediate supervisor. 
Zvarych Roman Vasylovych, Havretska Maryna Yosypivna, Andrukhiv Oleh Ihorovych, Kaleniuk Oksana Mykolayivna y Boiko Ihor Yosypovych

890 Legal basis for ethical behavior of civil servants in Ukraine: some problematic issues

Section 6 "Information Exchange" sets out the rules that civil servant and local government official should follow when communicating in the performance of their duties. In particular: 1) to provide information with the indication of the data confirming it; 2) timely provide, in accordance with the legislation, to other civil servants and officials of local selfgovernment the information necessary for the performance of their official duties; 3) present information materials and messages clearly, concisely and consistently for their unambiguous perception.

Besides, civil servant is obliged to adhere to the established protocol in relations with representatives of foreign authorities, international organizations and foreign institutions.

However, such an important issue as conflict of interest is presented in the Order only by the following sentence: "Civil servants and local government officials should prevent conflicts in relations with citizens, leaders, colleagues and subordinates" (Subparagraph 2, Paragraph, Section 2). Most likely, this is due to the fact that the Law of Ukraine "On Corruption Prevention" dedicates Section 5 to this issue.

As one can see, the legislation in this area is fragmented, and the provisions governing the ethics of conduct of civil service are contained in a number of regulations. The General Rules is the only special act that regulates relations in this area. However, as Malimon and Shevchenko (2015) correctly point out, the provisions contained in the General Rules are mostly justified and aimed at increasing the authority of a civil servant in society. However, unfortunately, these Rules are not provided with adequate legal means to influence civil servants. The Law of Ukraine "On Civil Service" did not stipulate the obligation of civil servant to comply with the requirements set forth in the General Rules of Conduct for Civil Servants. The absence of direct measures of responsibility for violating the rules of conduct of civil servants does not ensure their proper implementation, and the legal culture of civil servants and integrity in the exercise of official authority has not yet reached such a high level to be limited to voluntary compliance.

Therefore, according to the view of the authors (which we fully support), it is advisable to enshrine moral and ethical principles of the civil service in a legislative act (possibly in the Law "On civil service"), which will increase the degree of their binding on the civil servant. The same applies to local government officials.

From this point of view, the way of regulating ethical principles of public service in Estonia is well thought out. The Estonian Law on Public Service, having established the obligation to abide by the Code of ethics, submitted it in the annex to the Law. The Code of ethics for public service is the system of norms that determine the behavior of public servants and provide the principles of high service culture of public servants. For example, this 
Code enshrines such norms as: the use of public power only in the public interest; the exercise of public power on the basis of law; accompanying the exercise of public authority; preventing the creation of even an imaginary situation, which may call into question the impartiality and objectivity of the proceedings, etc. The Code outlines ethical principles of official conduct of a person, violations of which can be regarded as grounds for the imposition of disciplinary measures, the list and method of application of which are enshrined in Section 3 "Disciplinary liability of the officials" in the same Law On Civil Service (Tymoshchuk and Shkolyk, 2007).

In the United Kingdom and the United States this issue is regulated otherwise: the Civil Servants' Codes of Ethics apply in these countries.

Thus, in the United Kingdom, this document, on the one hand, regulates the ethics of professional activities of employees, ranging from the provision of services to the public to political advice to ministers, and on the other hand - recognizes the mutual responsibilities of employees and ministers. Therefore, the Code of Ethics consists of two parts:

1. Requirements for the service of ministers.

2. Requirements for other employees.

The Code is based on the need to implement the following principles: decency, honesty, objectivity and impartiality. Officials in their work should be guided by the following basic principles: 1 . Serving only the public interest - the refusal of any action to achieve material and financial benefits for themselves, their family and friends; 2. Incorruptibility - prevention of any financial or other dependence on external persons or organizations that may affect the performance of official debt; 3. Objectivity - an impartial solution to all issues; 4. Accountability - responsibility for actions taken before the public and the provision of complete information in the event of a public inspection; 5. Openness - the maximum informing of the society about all decisions and actions, their validity (thus reduction of the information is admissible if necessary observance of the higher public interests); 6 . Honesty - mandatory notification of their private interests related to public duties, taking all measures to resolve possible conflicts in favor of public interests; 7. Leadership - adherence to the principles of leadership and personal example in the implementation of standards of public life (European Information and Research Center, 2017).

The United States have developed their own code of ethics for each type of civil service. Thus, there is a Code of Ethical Conduct for Members of the Senate of Congress and a Code of Ethical Conduct for Members of the House of Representatives, the Law on the Ethics for Public Servants, etc. However, the most well-known and widely used document is the Standards of Ethical Conduct for Employees of the Executive Branch. 
Zvarych Roman Vasylovych, Havretska Maryna Yosypivna, Andrukhiv Oleh Ihorovych, Kaleniuk Oksana Mykolayivna y Boiko Ihor Yosypovych

This Code (Final Regulation of the U.S. Office of Government Ethics, 2017) establishes the following basic rules that all civil servants should follow: adhere to the Constitution, laws and ethical principles without regard to their own interests; have any financial interests that run counter to the conscientious performance of their duties; they are prohibited from demanding or accepting any gift or other item of monetary value from any person or organization; are obliged to make every effort to perform their duties; they are prohibited from using official position for own benefit; they are obliged to act impartially and give no preferences to any person or organization; they should protect and preserve federal property and not use it for purposes other than those provided by law; they cannot be engaged in other work or activities, etc.

The Code is differentiated and its rules provide for more severe $r$ sanctions for high-ranking officials. Penalties for violating the Code of conduct (from reprimand to dismissal) can be determined depending on the violation and the position of the employee, but in the case of public service personnel, such sanctions should be carried out under the standard administrative penalty procedure used in the public service.

It should be noted that the moral codes for officials also apply in France ("Code de déontologie"), Canada ("Conflict of Interests Act"), the Czech Republic (Ethical Code of Ethics and Substitution of Public Affairs), as well as in Croatia (Etički kodeks državnih službenika).

We believe that Ukraine should adopt the best practices of progressive countries and adopt its own Code of Ethics, which would fully reflect the principles of civil servants, set standards of ethical conduct, as well as sanctions for violations of these rules, regulate issues of prosecution for committing corruption offenses in the workplace and resolving conflicts of interest.

\section{Conclusions}

In this article, we reviewed the legal framework for regulating the rules of conduct for civil servants in Ukraine and found that this issue is regulated by a number of regulations. The main ones are the Constitution of Ukraine, the Laws of Ukraine "On Civil Service", "On Service in Local SelfGovernment Bodies", "On Corruption Prevention”. Some aspects devoted to this issue are reflected in a number of other legislative acts of our State. A special legal act regulating service ethics is the General rules of ethical behavior for civil servants and officials of local government, but due to the lack of an indication that the General Rules are mandatory in the Law of Ukraine "On Civil Service", the former are not provided with adequate remedies. 
That is why, based on the study of foreign experience, we concluded that Ukraine should adopt a single Code of Ethics for civil servants, as is done in many progressive countries.

Indeed, codes of ethics are considered an important means for combating corruption and secrecy. These codes are aimed at ensuring respect for public authorities by the society, establishing a productive, healthy atmosphere in the professional teams of public officials, limiting arbitrariness in relations with citizens and in internal professional relations (Vasylevska, 2015).

The drafting of codes of ethics for officials is also supported by international organizations. For example, Recommendation № R (2000) 10 (Recommendation of the Committee of Ministers to Member States 2000) emphasizes that the governments of the Member States should encourage, in accordance with national law and the principles of public administration, the adoption of national codes of conduct for civil servants, based on the Model Code of Conduct for Civil Servants, which is an annex to this Recommendation. The application itself defines international standards of honor and conduct for employees and prospects in this area.

In order for the code to be relevant and effective, it should include the following realistic goals: 1) promoting high standards of conduct; 2) strengthening public confidence in civil servants; 3) assistance in making management decisions.

In order for the code to be realistic, it must contain five elements, in particular: a) purpose; b) list of positive values to focus on; c) conceptual standards of what is possible and what is impossible; d) real sanctions; e) system of procedural guarantees. The code of conduct should fill the gap between the abstract provisions of the law, which are general principles of conduct, and specific recommendations and rules of conduct in everyday situations. It should reduce the degree of uncertainty and give advice on where the employee should address when such a difficult situation arises (Malimon and Shevchenko, 2015).

\section{Bibliographic References}

DEWEY, John. 2008. Moral Principles in Education. Book Jungle. London, United Kingdom.

EASTON, David. 1962. The current meaning of "Behavioralism" in political science. In J. S. Charlesworth (Ed.), The limits of behavioralism (pp. 8 25). The American Academy of Political and Social Science. Philadelphia, USA. 
Zvarych Roman Vasylovych, Havretska Maryna Yosypivna, Andrukhiv Oleh Ihorovych, Kaleniuk Oksana Mykolayivna y Boiko Ihor Yosypovych

894 Legal basis for ethical behavior of civil servants in Ukraine: some problematic issues

EUROPEAN INFORMATION AND RESEARCH CENTER. 2017. Rules of ethical conduct for civil servants (experience of the European Union and the United States). Available online. In: http://euinfocenter.rada.gov. ua/uploads/documents/29069.pdf. Date of consultation: 21/01/2020.

FINAL REGULATION OF THE U.S. OFFICE OF GOVERNMENT ETHICS. 2017. Standards of Ethical Conduct for Employees of the Executive Branch, codified in 5 C.F.R. Part 2635 as amended at 81 FR 81641 (effective January 1, 2017). Available online. In: https://www.oge.gov/ Web/oge.nsf/o/5438912F316AoD26852585B6005A1599/\$FILE/ SOC\%20as\%20of\%2081\%20FR\%2081641\%20FINAL.pdf. Date of consultation: 21/01/2020.

KOLOMOIETS, Tetiana; KOLPAKOV, Valerii; KUSHNIR, Serhii; ALIMOV, Kyrylo; DIKHTIIEVSKYI, Petro. 2019. "Monitoring the Lifestyle of Public Officials- a Means of Preventing Corruption or Legalized Interference in a One's Private and Personal Life?” In: Amazonia Investiga. Vol. 8, No. 24, pp. 267 - 274. Available online. In: https://amazoniainvestiga.info/ index.php/amazonia/article/view/982. Consultation date: 21/01/2020.

KOLOMOIETS, Tetiana; KOLPAKOV, Valerii; KUSHNIR, Serhii; MAKARENKOV, Oleksii; HALITSYNA, Natalia. 2020. ““External Activities\&quot; Of Public Officials: What Are the Anti-Corruption Standards of Legal Regulation?” In: Amazonia Investiga. Vol. 9, No. 26, pp. 191 - 196. Available online. In: https://amazoniainvestiga.info/index. php/amazonia/article/view/1136. Consultation date: 21/03/2020.

KUHN, Tomas; WEIBLER, Jürgen. 2004. "Necessity, approaches and prerequisites for ethically conscious management of subordinates" In: Problems of management theory and practice. No. 5, pp. $119-127$.

LAW OF UKRAINE. 1971. Law 322-VIII/1971, December 10. Labor Code of Ukraine. The Verkhovna Rada of Ukraine. Available online. In: https:// zakon.rada.gov.ua/laws/show/322-08\#Text. Date of consultation: 21/01/2020.

LAW OF UKRAINE. 1996. Law 254k/96-VR/1996, June 28. The Constitution of Ukraine. The Verkhovna Rada of Ukrain. Available online. In: https://zakon.rada.gov.ua/laws/show/254\%Do\%BA/96\%Do\%B2\%D1\%80\#Text. Date of consultation: 21/1/2020.

LAW OF UKRAINE. 2001. Law 2493-III/2001, June 07. On Service in Local Self-Government Bodies. The Verkhovna Rada of Ukraine. Available online. In: https://zakon.rada.gov.ua/laws/show/2493-14\#Text. Date of consultation: 21/01/2020. 
LAW OF UKRAINE. 2014. Law 1682-VII/2014, September 16. On the clearance of the authorities. The Verkhovna Rada of Ukraine. Available online. In: https://zakon.rada.gov.ua/laws/show/1682-18\#Text. Date of consultation: 21/01/2020.

LAW OF UKRAINE. 2014. Law 1700-VII/2014, October 14. On Corruption Prevention. TheVerkhovna Rada of Ukraine. Available online. In: https:// zakon.rada.gov.ua/laws/show/1700-18\#Text. Date of consultation: 21/01/2020.

LAW OF UKRAINE. 2016. Law 889-VIII/2016, December 12. On the Public Service. The Verkhovna Rada of Ukraine. Available online. In: https:// zakon.rada.gov.ua/laws/show/889-19\#Text. Date of consultation: 21/1/2020.

LAW OF UKRAINE. Law 4722-VI/2012, May 17. On the rules of Ethical Behavior. The Verkhovna Rada of Ukraine. Available online. In: https:// zakon.rada.gov.ua/laws/show/4722-17\#Text. Date of consultation: 21/11/2020.

MALIMON, Vitalii; SHEVCHENKO, Nataliia. 2015. "Updating codes of ethics in the context of the modernization of public administration" In: Scientific and Informational Bulletin of Ivano-Frankivsk University of Law Named after King Danylo Halytskyi. No. 11, pp. 79 - 85 .

ORDER OF THE NATIONAL AGENCY OF UKRAINE FOR CIVIL SERVICE AFFAIRS. 2016. August 05. On the statement of the General rules of ethical behavior for civil servants and officials of local government. The Verkhovna Rada of Ukraine of August 05, 2016 no. 158. Available online. In: https://zakon.rada.gov.ua/laws/show/z1203-16\#Text. Date of consultation: $21 / 01 / 2020$.

RECOMMENDATION OF THE COMMITTEE OF MINISTERS TO MEMBER STATES. 2000. On codes of conduct for public officials, adopted at its 106th session on 11 May 2000. Available online. In: https://rm.coe. int/16806cc1ec. Date of consultation: 21/01/2020.

SOROKINA, Nataliia. 2017. "Analysis of the main requirements to the ethical behavior of civil servants in Ukraine: legal aspects" In: Aspects of public administration. Vol. 5, No. 39-40, pp. 13 - 18.

TYMOSHCHUK, Viktor; SHKOLYK, Andrii. 2007. Public service: foreign experience and propositions for Ukraine. KonusYu. Kyiv, Ukraine.

VASYLEVSKA, Tetiana. 2015. Ethics of public administration: textbook. NADU. Kyiv, Ukraine.

WRIGHT, Glen. 1994. Public Administration (translation from English). Osnovy. Kyiv, Ukraine. 

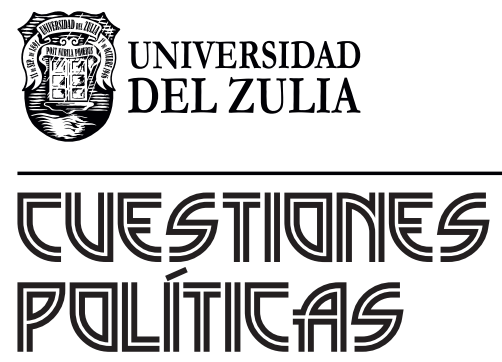

Vol.39 No 68

Esta revista fue editada en formato digital y publicada en enero de 2021, por el Fondo Editorial Serbiluz, Universidad del Zulia. Maracaibo-Venezuela 